\title{
Simulation of bearing capacity of bored piles
}

\author{
Ahmed Majeed $^{1, *}$, Olla Haider $^{1}$ \\ ${ }^{1}$ Building and Construction Engineering Department, University of Technology, Baghdad-Iraq
}

\begin{abstract}
This study focuses on how one can possibly predict the ultimate load for the piles that did not reach failure. This challenge was acquired through Chin- Konder method by which, the estimated settlement that correspond to failure load is well defined. Hence, this research aims to make a comparative study between the results of pile load tests carried out in Al-Basrah sewage treatment plant project, and those results induced from the numerical analysis in term of ultimate pile capacity. Consequently, it may give a clear idea on the ability of numerical simulation in getting close to the actual behavior of piles. In the current study, a numerical study using Plaxis 3D Foundation program has been performed on bored piles by the assistance of site investigations of soil. Mohr- Coulomb and linear elastic models were adopted in the simulation for soil and pile respectively. Ten bored piles were used in this analysis under different values of loading. The diameter and length of pile are $0.6 \mathrm{~m}$ and $24 \mathrm{~m}$ respectively. The test results indicate that, an excellent agreement has been found as a response of pile capacity between the field and numerical studies. Also, ideal load- settlement curves were created using Chin- Konder method to predict the failure load of bored piles. Also, the results have demonstrated that, the pile capacity obtained from the simulation process is larger about $51 \%$ than that design load estimated before the design of piles. This may present a priority to use the finite element method to be accounted as an effective approach in the primary analysis.
\end{abstract}

\section{Introduction}

The noticeable disparity in pile design techniques and the uncertainties associated to the traditional theories due to the huge numbers of parameters involved in analysis, necessitates that to alternative analytical ways is essential to account for the whole behavior of piles. In this study, a numerical modeling using Plaxis 3D Foundation software was performed on bored piles placed into layered soil to validate the field test results which has been implemented under same conditions.

Thereupon, the traditional methods for calculating the problems of pile bearing capacity are still insufficient to be accounted in design. As presented, the simplified analysis for the conventional theories ignore some of the facets involved making the solutions inaccurate and deficient to be relied unless verified by certain reliable methods.

Thus, the main role for using the finite element method, is to thoroughly understand and realize some of the practical aspects of bored piles which are hard to obtain using the conventional design methods. These traditional methods have emerged over years to afford conservative solutions seeking the cost and safety, therefore it is important to revise and adjust the bearing capacity with those results obtained from the field load tests especially for strategic projects.
Herein, the pile load test is normally carried out to verify and to check the response of foundations in term of bearing

capacity and settlement. The major challenge in this concern is not how to get the design load of pile, but estimation of the behavior of pile that did not reach to failure is still dialectical. Thus, restoring to alternative approaches to expect the actual work load would be greatly required. There are several studies related with this scope, [7] demonstrated that, for $1.2 \mathrm{~m}$ diameter bored cast in-situ piles executed in residual soils, a reasonable agreement has been gained between the ultimate pile capacity obtained from the finite element analyses in 2D Plaxis and full scale tests. The values of pile settlement in both analysis were 2.6 and $4.9 \mathrm{~mm}$ under the maximum load equal to 825 tons. [8] analyzed the results of four static pile load tests and a these results have been validated using Plaxis 3D Foundation program. The model used in the analysis is Mohr coulomb. The pile length and diameter are $9 \mathrm{~m}$ and $0.62 \mathrm{~m}$ respectively. Plaxis and in-situ measured loaddisplacement curves showed a good correlation.

[4] carried out a comparative study in order to assess the behavior of driven piles which have a diameter of $0.35 \mathrm{~m}$ and embedded length of $10-12 \mathrm{~m}$ supported 8 storiesbuilding. The case study compared the field results with

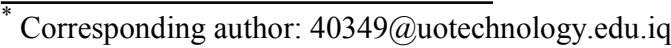


numerical simulation using Plaxis 2D. The result of finite element analysis shows that the ultimate axial capacity is in good convergence with the axial capacities obtained using empirical method and field results.

[6] Found out that, the simulation of cast in situ piles with a diameter of $620 \mathrm{~mm}$ and penetration length equal to $15 \mathrm{~m}$ is an effective method in design. The piles were installed in silt sand, and the numerical analysis has been done using Plaxis 3D software. The test results displayed a pronounced agreement between the two studies in term of load- settlement curves.

[10] Performed a numerical analysis on a bored pile with dimensions of $0.6 \mathrm{~m}$ diameter and $26 \mathrm{~m}$ in length, and subjected to axial load using 2D Plaxis software. According to the borehole details, the pile is penetrated in a clayey silt and decomposed of organic matter. The simulation results in 2D Plaxis showed a good agreement between the field and the finite element results.

In summary, this research displays a numerical investigation for the bored piles executed in Al-Basrah sewage treatment project and a comparison of pile capacity is performed with the field results at failure to understand how far the numerical approaches get close to field ones.

\section{Site investigation and soil details}

The project is located at Hamdan region which is a part of Al-Basrah governorate. The field explorations were carried out on the soil layers to obtain their characterization. Ten boreholes were made at different zones, each one describes stratification of soil under a certain structure. According to [2], drilling was performed using flight auger. The undisturbed samples marked (U) were obtained using Shelby tubes. Split spoon samples (SS) were obtained from standard split spoon used in a Standard Penetration Test (S.P.T), which was performed for each test boring at different intervals depending on the stratification of the soil.

The N-Values for S.P.T. and the variation of water content with depth are shown in Figures (1) and (2) respectively. Then, the $\mathrm{N}$ values are corrected by taking a percent of $60 \%\left(\mathrm{~N}_{60}\right)$ and the water content values are somehow useful to calculate the unit weight of the soil in different cases (wet or saturated), which are basically required in the numerical analysis.

The soil investigation along the depth of boreholes exhibits that, the type of brown/gray silty clay or clayey silt with some organic matters or salts at certain depths was shown to be prevailed. Further drilling up to $21 \mathrm{~m}$ presented sillty sand to dense sand and beyond which the soil is very dense sand with $\mathrm{N}$-values up to 50 according to soil report.
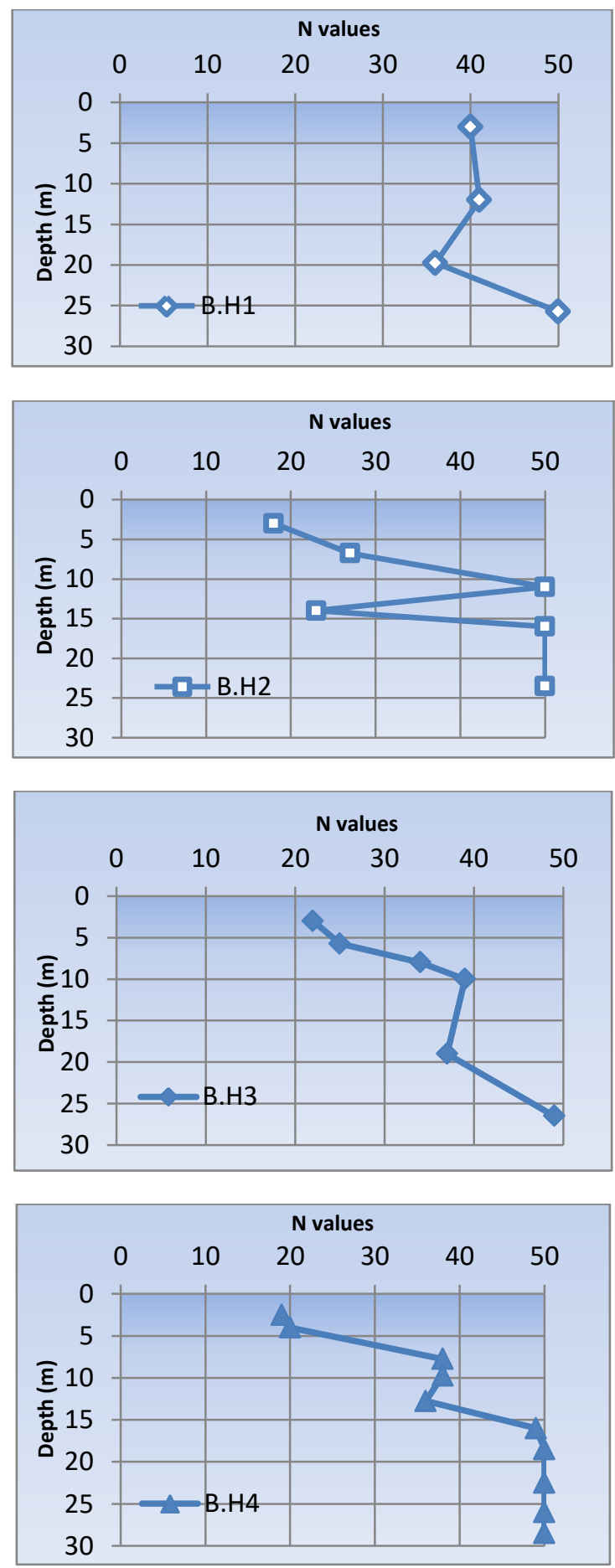

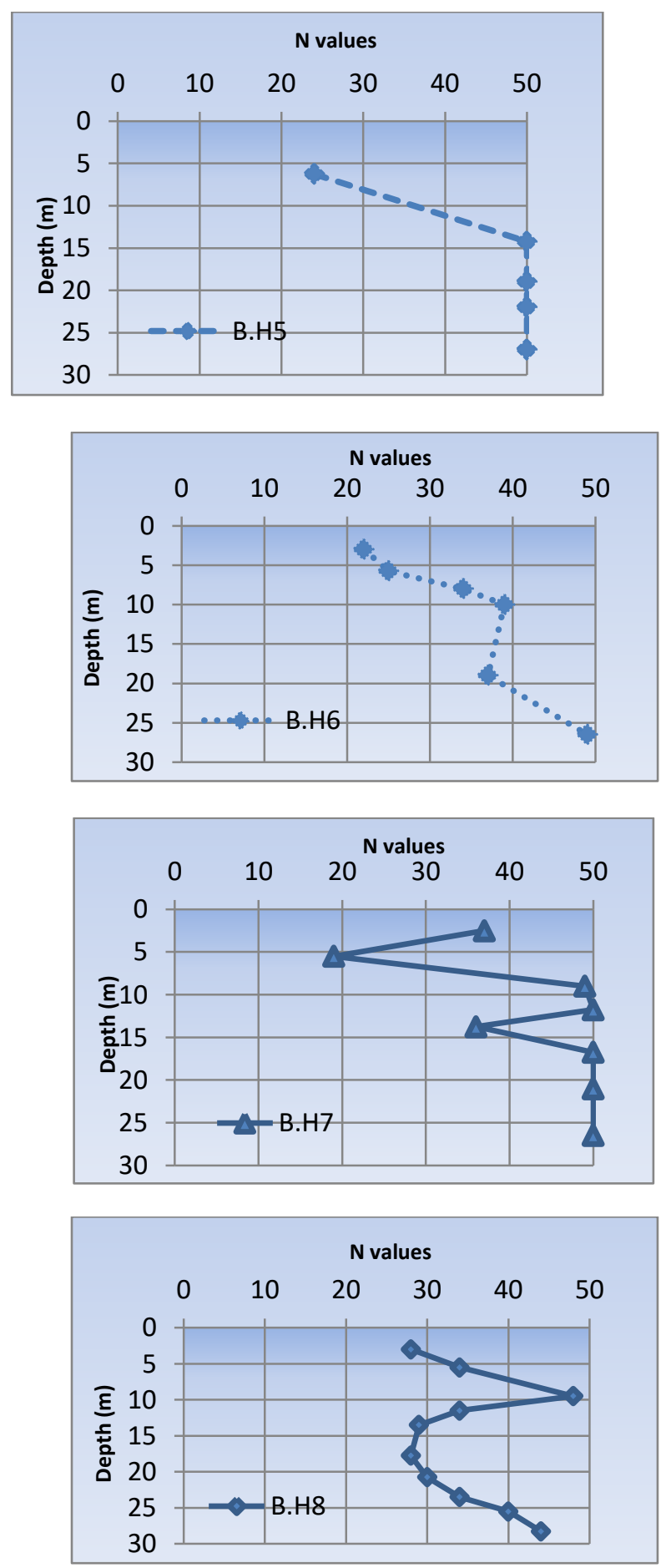
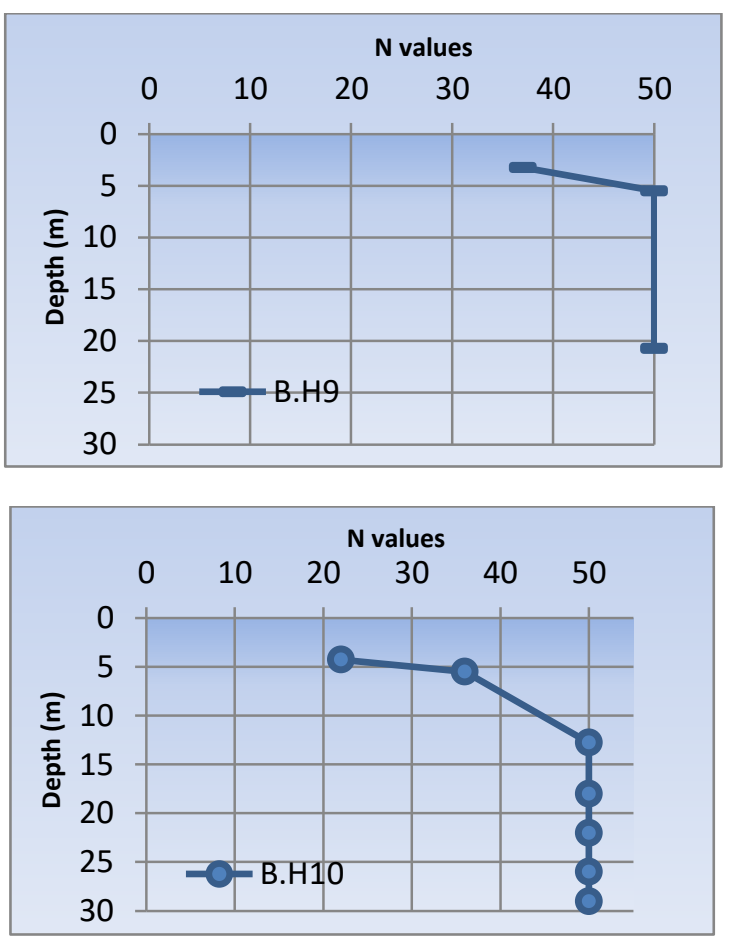

Fig.1. Variation of standard penetration values $(\mathrm{N})$ with depth for different boreholes
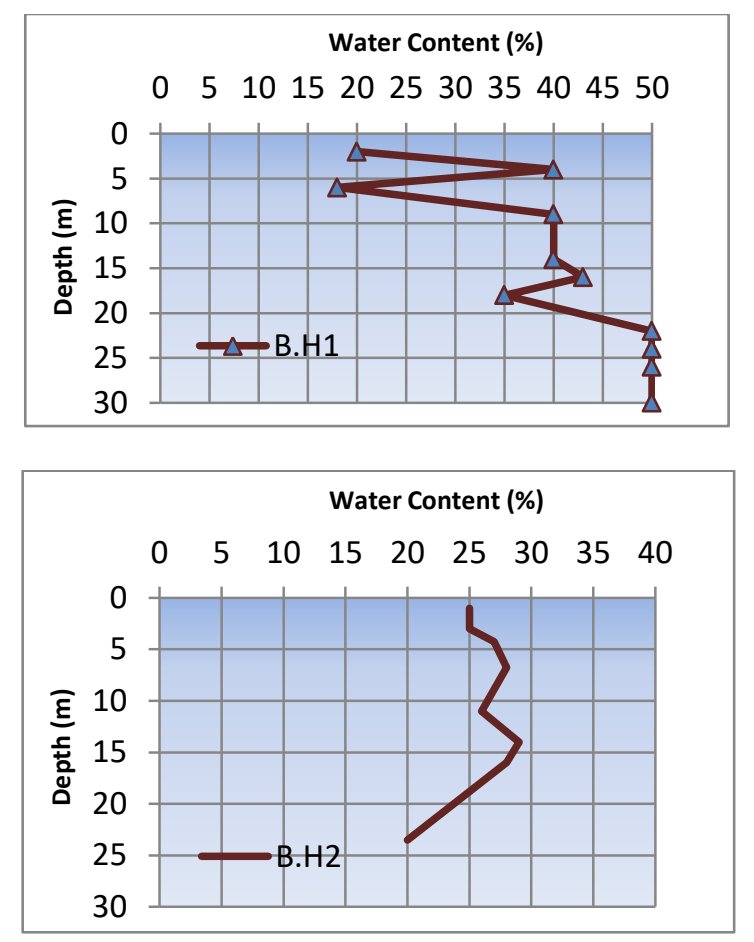

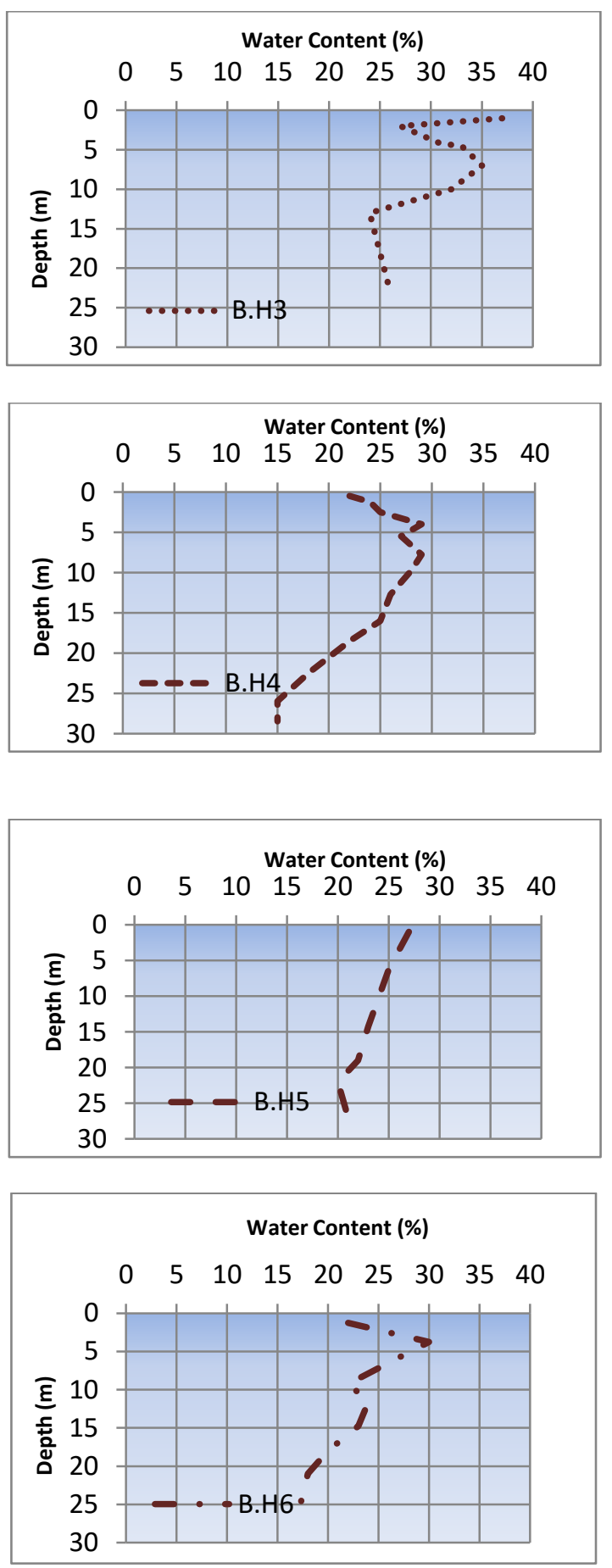
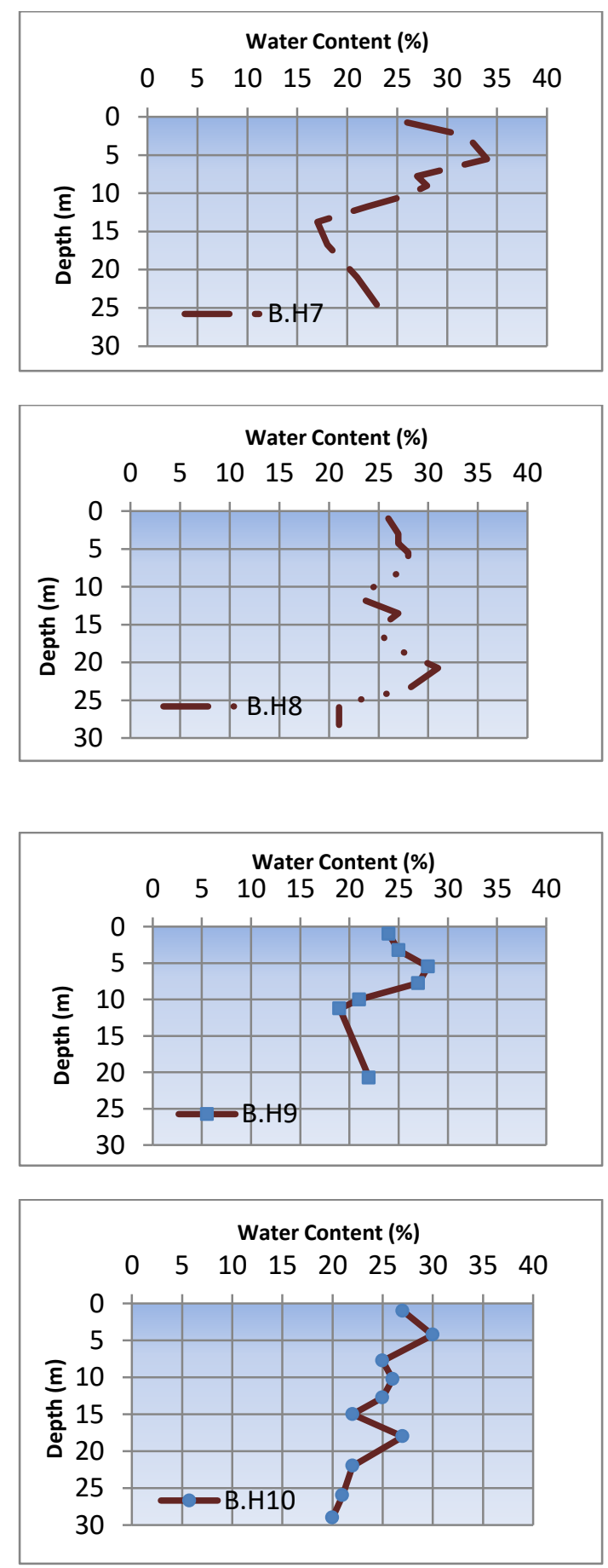

Fig.2. Variation of water content values with depth for different boreholes.

An exhaustive analysis was made to obtain the soil properties for each type. The values of specific gravity, void ratio and the unit weights at dry and saturated states for each layer which empanel within the physical soil characterization were calculated based on the visual soil classification with the aid of water content logs. The shear strength parameters which are basically relied on specimens extracted from undisturbed samples were obtained (undrained shear strength $\mathrm{c}_{\mathrm{u}}$ ) especially for the 
fine grained soil, nonetheless for some reason there were depths at which no samples had been taken, the shear strength details were induced based on standard values found by [9] which stipulate that the $\mathrm{N}$-values and soil consistency must be known.

The stiffness properties were also computed using triaxial test for the samples taken from undisturbed type, but for the layers at which it is too difficult to extract an intact samples to be tested, feasible magnitudes of modulus of elasticity and Poisson's ratio for each type of soil have been chosen based on soil type and according to [3].

For the coarse grained soil or sand mixed with few quantities of silt or clay, the angle of internal friction $\varphi$ was determined based on the corrected values of SPT test, for all the cases the $\mathrm{N}_{60}$ is predominant. The correlation between the angle of internal friction and $\mathrm{N}_{60}$ that is proposed by [5] is expressed as:

$$
\phi=\sqrt{ } 20 \text { Ncor }+20
$$

The full details of soil properties only for borehole No.1 will be listed in Table 1, just to demonstrate how these parameters have been acquired.

Table 1. Borehole log and soil properties No.1

\begin{tabular}{|c|c|c|c|c|c|}
\hline \multirow{2}{*}{$\begin{array}{l}\text { Property } \\
\text { index }\end{array}$} & \multicolumn{5}{|c|}{ Depth m (from- to) } \\
\hline & $0-2$ & $2-4$ & $4-6$ & $6-18$ & $18-30$ \\
\hline $\begin{array}{c}\text { Soil } \\
\text { Description }\end{array}$ & $\begin{array}{l}\text { Brow } \\
\text { n silty } \\
\text { clay }\end{array}$ & $\begin{array}{l}\text { Silty } \\
\text { sand }\end{array}$ & $\begin{array}{l}\text { Stiff } \\
\text { silty } \\
\text { clay }\end{array}$ & $\begin{array}{l}\text { Claye } \\
\text { y sily } \\
\text { with } \\
\text { organi } \\
\text { c }\end{array}$ & $\begin{array}{l}\text { Grey } \\
\text { silty } \\
\text { sand }\end{array}$ \\
\hline $\begin{array}{l}\text { Modulus of } \\
\text { elasticity, } \mathrm{E}_{\mathrm{s}} \\
\text { (MPa) }\end{array}$ & 6.0 & 14.0 & 4.5 & 45 & 50 \\
\hline $\begin{array}{l}\text { Poisson's } \\
\text { ratio, } v\end{array}$ & 0.3 & 0.3 & 0.4 & 0.3 & 0.3 \\
\hline $\begin{array}{l}\text { Angle of } \\
\text { internal } \\
\text { friction, } \varphi\end{array}$ & - & $43^{\circ}$ & - & - & $45^{\circ}$ \\
\hline $\begin{array}{c}\text { Cohesion, c } \\
\left(\mathrm{kN} / \mathrm{m}^{2}\right)\end{array}$ & 36.0 & - & 47 & 220 & - \\
\hline $\begin{array}{c}\text { Angle of } \\
\text { Dilation, } \psi\end{array}$ & - & 13 & - & - & 15 \\
\hline $\begin{array}{c}\text { Dry unit } \\
\text { weight, } \gamma \mathrm{d} \\
\left(\mathrm{kN} / \mathrm{m}^{3}\right)\end{array}$ & 16.0 & 16.8 & 17.0 & 15.6 & 16.5 \\
\hline $\begin{array}{l}\text { Total unit } \\
\text { weight, } \gamma \mathrm{t} \\
\left(\mathrm{kN} / \mathrm{m}^{3}\right)\end{array}$ & 20.0 & 19.0 & 20.0 & 19.3 & 19.5 \\
\hline
\end{tabular}

\section{Pile description}

Full scale of bored piles in circular cross sections have been evaluated under static compressive load tests. A total number of ten piles were executed at different zones of the project. The structures that were supported by these piles and their function are presented in Table 2. The diameter and length of piles used are 0.8 and $24 \mathrm{~m}$ respectively. The pile load tests were carried out on working and trial piles by means of Kent ledge dead weights according to [1]

Table 2. Summary of piles-supported structures and their function used in this study

\begin{tabular}{|c|c|c|c|c|}
\hline No. & Type of structure & Pile type & $\begin{array}{c}\text { Design } \\
\text { load } \\
\text { (Ton) }\end{array}$ & $\begin{array}{c}\text { Testing } \\
\text { load } \\
\text { (Ton) }\end{array}$ \\
\hline 1 & $\begin{array}{c}\text { Clarifier Tank } \\
\text { TP1 }\end{array}$ & working & 50 & 100 \\
\hline 2 & $\begin{array}{c}\text { Clarifier Tank } \\
\text { TP2 }\end{array}$ & working & 50 & 100 \\
\hline 3 & Aeration Tank & working & 90 & 180 \\
\hline 4 & $\begin{array}{c}\text { Clarifier Tank } \\
\text { TP3 }\end{array}$ & Trial & 50 & 150 \\
\hline 5 & $\begin{array}{c}\text { Clarifier Tank } \\
\text { TP3 }\end{array}$ & Trial & 50 & 150 \\
\hline 6 & $\begin{array}{c}\text { Distribution } \\
\text { Chamber }\end{array}$ & Trial & 50 & 150 \\
\hline 7 & $\begin{array}{c}\text { Effluent pumping } \\
\text { station }\end{array}$ & Trial & 50 & 150 \\
\hline 9 & $\begin{array}{c}\text { Chlorination Tank } \\
\text { Portable water } \\
\text { tank 1 }\end{array}$ & Trial & 50 & 150 \\
\hline 10 & $\begin{array}{c}\text { Portable water } \\
\text { tank 2 }\end{array}$ & working & 50 & 100 \\
\hline
\end{tabular}

\section{Finite element analysis and mesh generation}

The numerical investigation of the bored piles under axial loads were precisely analyzed. Plaxis 3D Foundation software version 1.6 was adopted. The mesh created in simulation process was medium and due to the variation of shear strains near the interface between the pile and soil, the mesh got finer.

The pile and surrounding soil were modeled using linear elastic and Mohr-coulomb models respectively. The first model depended on stiffness parameters of the pile as shown in Table 3. The basic requirements of the latter model are the shear strength parameters which are involved the cohesion $\mathrm{c}$ and the angle of internal friction $\varphi$ as well as the dilation angle $\psi$ beside the modulus of elasticity $\mathrm{E}_{\mathrm{s}}$ and Poisson's ratio $v$. The pile is assumed as a rigid member, and the interaction at the pile-soil interface must be well defined. Thus, $\mathrm{R}_{\text {int }}$ value was taken equal to 0.7 due the nature of shear stresses generated along the pile shaft after the fully casting period is reached. 
The 15- node wedge element was employed in this study. The 15-node wedge element is composed of 6-node triangles in horizontal direction and 8-node quadrilaterals in vertical direction. The wedge element presents conceivable results and capable to well represent the cases where the strain intensity is localized.

Table 3. Pile details used in the current study

\begin{tabular}{|c|c|}
\hline Identification & Value \\
\hline Material Model & Linear elastic \\
\hline Modulus of elasticity, $\mathrm{E}_{\mathrm{p}}\left(\mathrm{kN} / \mathrm{m}^{2}\right)$ & 25700000 \\
\hline Poisson's ratio, $v$ & 0.2 \\
\hline Type of Material & Non porous- concrete \\
\hline Material density $\left(\mathrm{kN} / \mathrm{m}^{3}\right)$ & 24 \\
\hline
\end{tabular}

In order to define the cases to be analyzed, a numerical analysis has been performed to simulate the entire behavior of full scale bored piles under compression loads that were carried out on piles of $24 \mathrm{~m}$ in total length and $0.6 \mathrm{~m}$ in diameter. The boundaries of mesh used in this analysis were chosen to be $(30 \times 30 \mathrm{~m})$. Numbers of elements and nodes in generated mesh are 2880 and 8409 respectively. These dimensions are considered satisfactory for eliminating any effects of the boundaries on the test results. The whole system of test corresponding to the mesh layout and soil layers is shown in Figure 3.

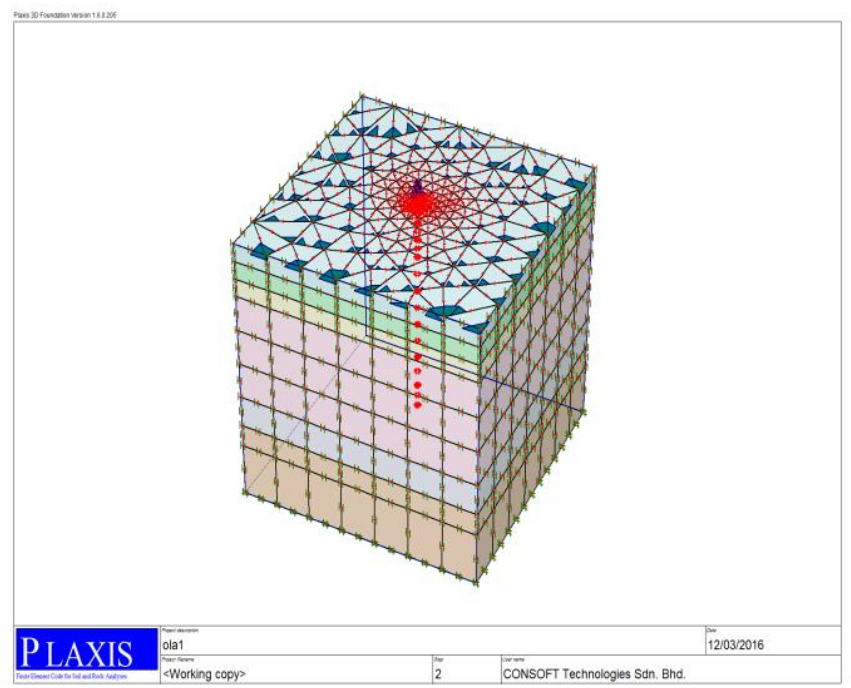

Fig 3. Three dimensional mesh for single pile embedded in layered soils

\section{Presentation of test results}

The results obtained from the numerical analysis done using Plaxis 3D foundation program and those gained from the field load tests have been presented. Both studies were performed under same soil and loading conditions, by the assistance of site investigations that were carried out for the required project. Also, the load- settlement curves for the piles examined in the present study will be introduced.
The failure load of piles for the numerical and field results will also be compared, to understand how the finite element technique could be used as a powerful tool in piles design. Figures 4 to 13 present the load- settlement curves of bored piles for the field and numerical studies. The input data adopted in the numerical simulation have exactly relied on the same site investigation of soil, pile properties and the nature of loading that applied on the pile during the load test in the field. This process is to satisfy all the requirements of pile simulation, and to reflect closely as possible the actual behavior of piles

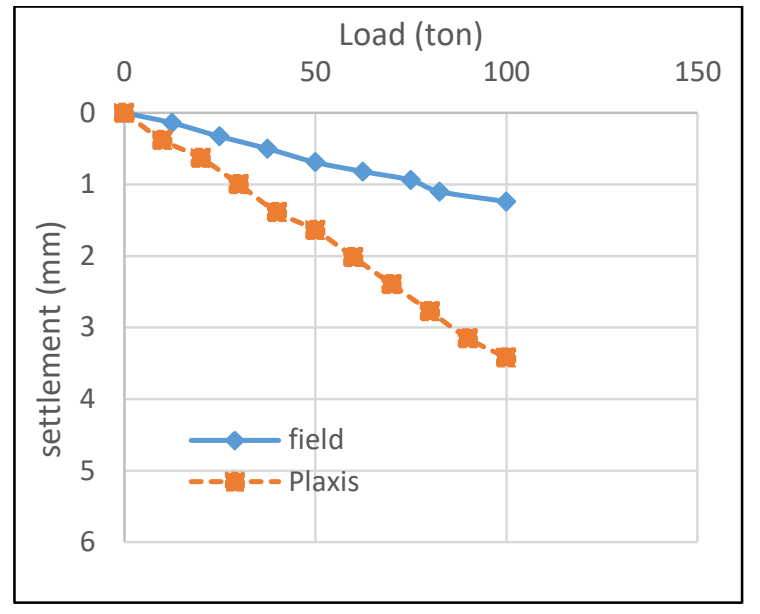

Fig. 4. Load-settlement curve for bored pile under Clarifier Tank TP1

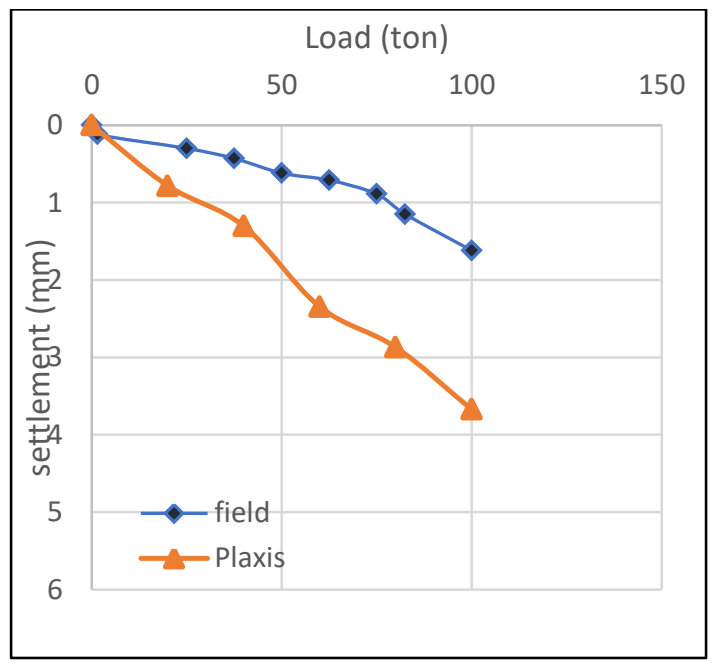

Fig. 5. Load-settlement curve for bored pile under Clarifier Tank TP2 


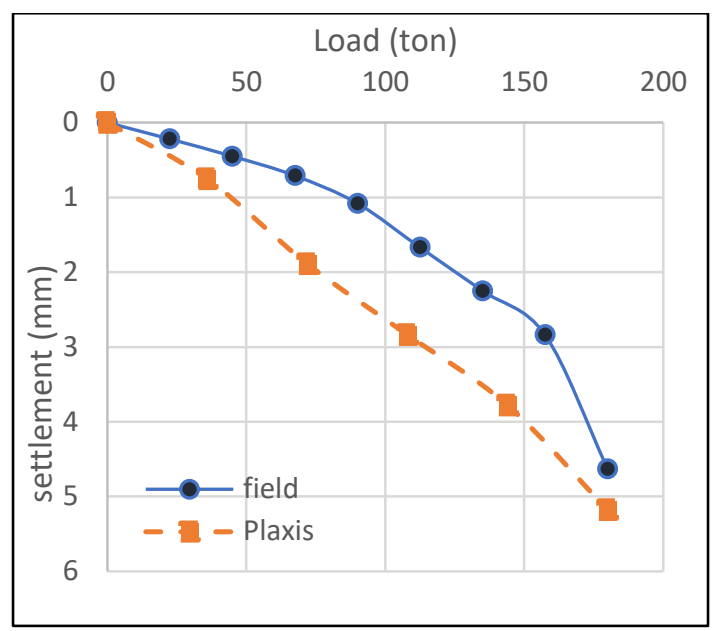

Fig. 6. Load-settlement curve for bored pile under Aeration Tank

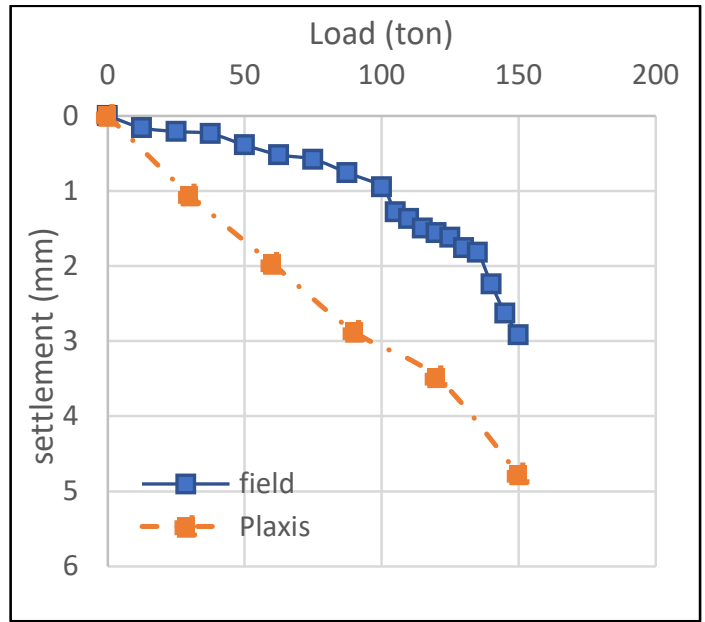

Fig. 7. Load-settlement curve for bored pile under Clarifier Tank TP3

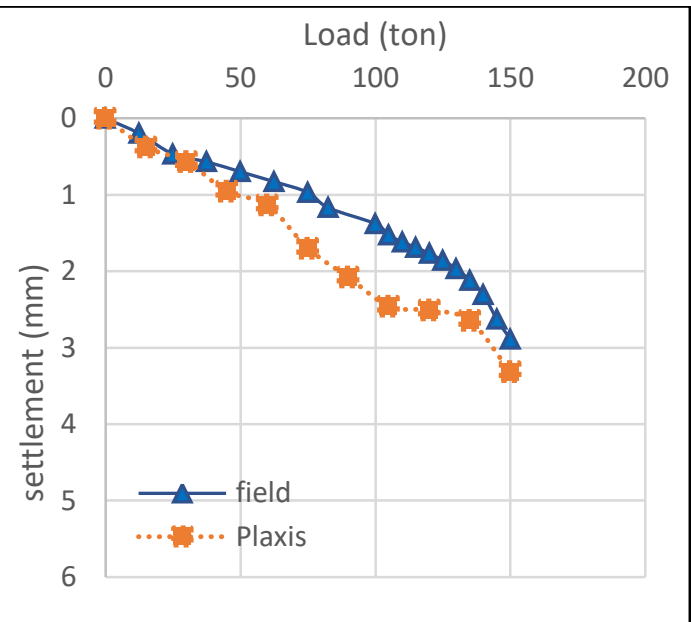

Fig. 8. Load-settlement curve for bored pile under Clarifier Tank TP4

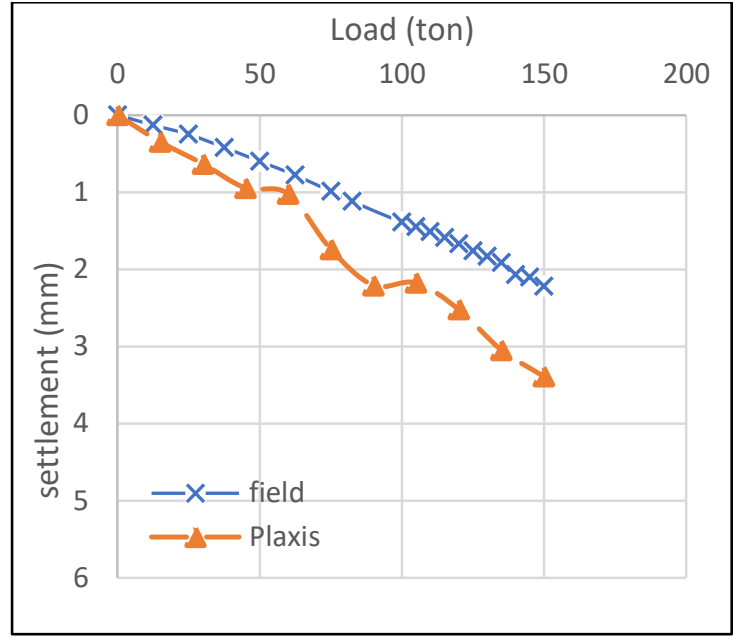

Fig. 9. Load-settlement curve for bored pile under Distribution Chamber

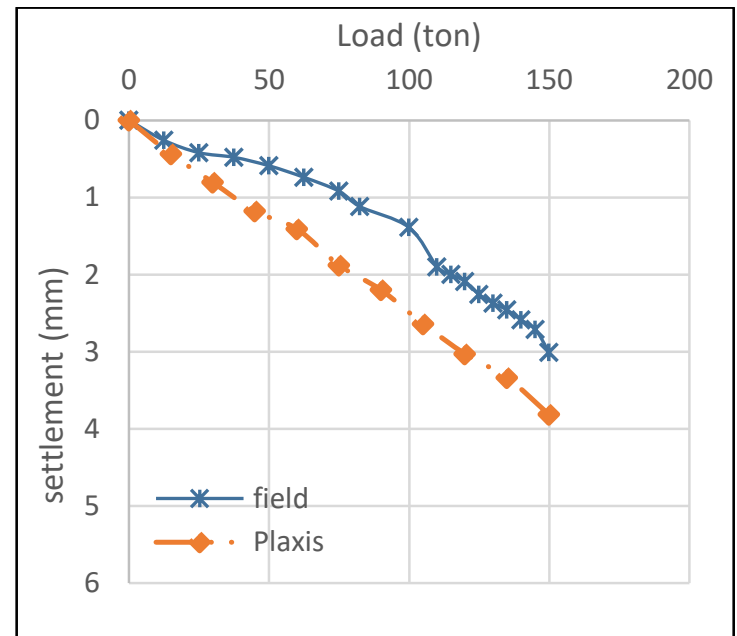

Fig. 10. Load-settlement curve for bored pile under Effluent pumping station

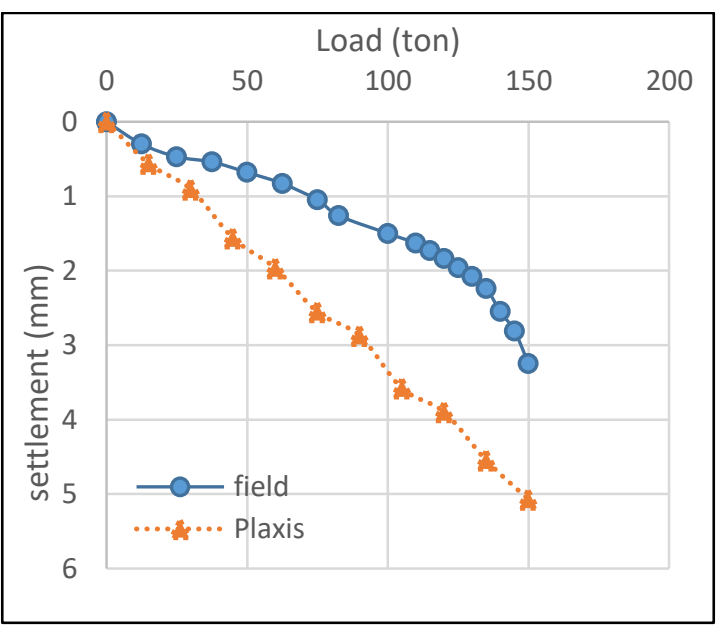

Fig. 11. Load-settlement curve for bored pile under Chlorination Tank 


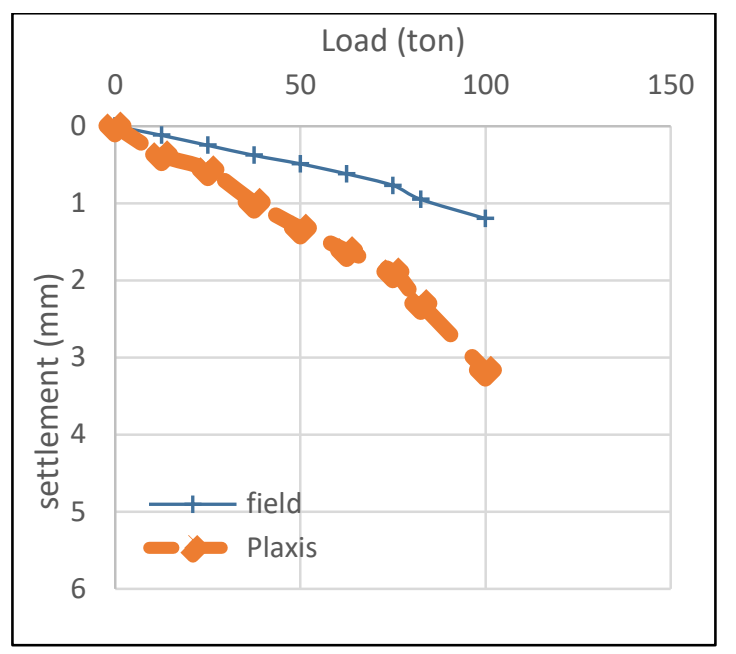

Fig. 12. Load-settlement curve for bored pile under Portable water Tank 1

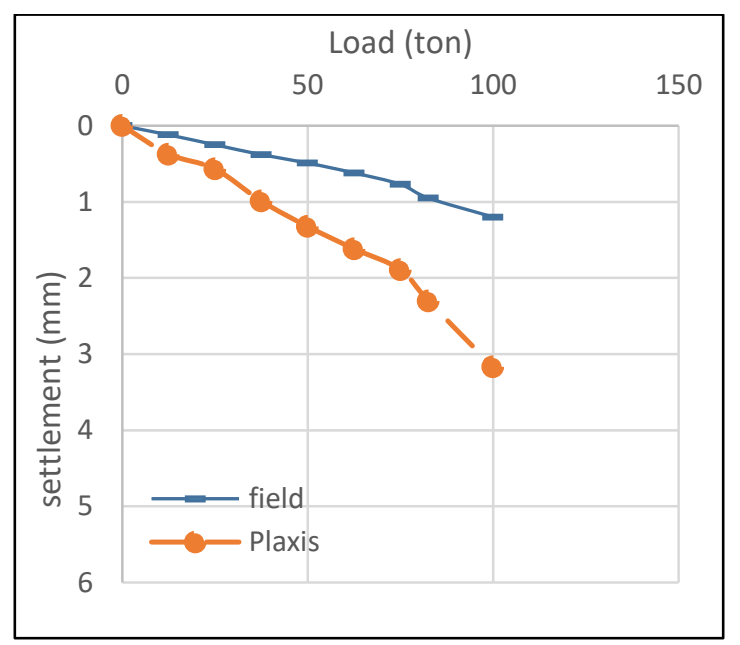

Fig. 13. Load-settlement curve for bored pile under Portable water Tank 2

It is noticed that from the figures above, the trend of curves for both studies is approximately similar. This may lead to the fact that, the behavior of piles under an applied load approaches to be same. Also, for all the piles, the values of settlement recorded from the analysis give a good impression on the accuracy and convergence between the numerical and field load test results.

However, the noticeable agreement educed from this analysis may be attributed to the correct employment of modeling details such as inserting actual representative values of soil properties and pile characteristics, in addition to the suitable representation of pile installation in the simulation process, at which the entire behavior of bored pile is significantly affected. A comparison in terms of settlement for the numerical and field tests under testing load is listed in Table 4.
Table 4. Values of settlement recorded from the analyses of pile tests

\begin{tabular}{|c|c|c|c|}
\hline No. & Type of structure & $\begin{array}{c}\text { Settlement } \\
\text { values (mm) } \\
\text { (Field) }\end{array}$ & $\begin{array}{c}\text { Settlement } \\
\text { values } \\
(\mathrm{mm}) \\
\text { (Numerical) }\end{array}$ \\
\hline 1 & Clarifier Tank TP1 & 1.24 & 3.24 \\
\hline 2 & Clarifier Tank TP2 & 1.62 & 3.67 \\
\hline 3 & Aeration Tank & 4.6 & 5.2 \\
\hline 4 & Clarifier Tank TP3 & 2.92 & 4.8 \\
\hline 5 & Clarifier Tank TP4 & 2.89 & 3.31 \\
\hline 6 & $\begin{array}{c}\text { Distribution } \\
\text { chamber }\end{array}$ & 2.22 & 4.0 \\
\hline 7 & $\begin{array}{c}\text { Effluent pumping } \\
\text { station }\end{array}$ & 3.01 & 3.82 \\
\hline 8 & Chlorination Tank & 3.25 & 5.07 \\
\hline 9 & $\begin{array}{c}\text { Portable water } \\
\text { tank1 }\end{array}$ & 1.2 & 3.17 \\
\hline 10 & $\begin{array}{c}\text { Portable water } \\
\text { tank2 }\end{array}$ & 1.79 & 3.1 \\
\hline
\end{tabular}

\subsection{Prediction of pile capacity from field and numerical test results}

Usually, the aim of pile load test is to obtain the safe capacity of tested pile, and to verify the design calculations computed by traditional methods. So, it is necessary to estimate the pile capacity for the numerical and field studies to withstand on the safe value of pile capacity without failure.

The results of current study demonstrate that, no pile has been reached to the failure. All piles have recorded settlement values less than the allowable limitations for shear failure. This may be referred to numerous facets, for example although the working piles are not loaded to the failure, on the other side, even the trial piles did not fail under the testing load. Therefore, the conventional methods used in piles design give underestimated results.

However, to envision the failure load (ultimate capacity) of piles and since all the tested piles did not reveal a tendency to fail, it is too hard to predict the ultimate capacity in this case, unless an alternative way is used to solve this problem.

A Chin Konder method was adopted in the current study, to expect and track the behavior of pile throughout the stages of loading, until the required level of settlement is satisfied. In this technique, ultimate pile capacity was estimated by using the tangential method. So, the steps used in this method in which the pile capacity has been 
achieved, will be displayed as the following: each settlement point is divided with its corresponding load and plot the resulting value against the settlement. The slope of this line is $\mathrm{C}_{1}$ and interception with $\mathrm{y}$-axis is $\mathrm{C}_{2}$. If required the pile load at any level of settlement, an ideal curve can be normally generated using the following equation:

$$
\mathrm{Q}=\delta /(\mathrm{C} 1 \delta+\mathrm{C} 2)
$$

Where:

Q: the applied load.

$\delta$ : settlement and,

$\mathrm{C} 1$ and $\mathrm{C} 2$ : slope of the straight line and y-interception of the straight line respectively.

One example (pile under clarifier Tank TP4) will be reviewed in details, and how the steps of Chin Konder method are applied to obtain the ultimate pile capacity and get an ideal curve. The symbols $\mathrm{C}_{1}$ and $\mathrm{C}_{2}$ are obtained from Figure 14.

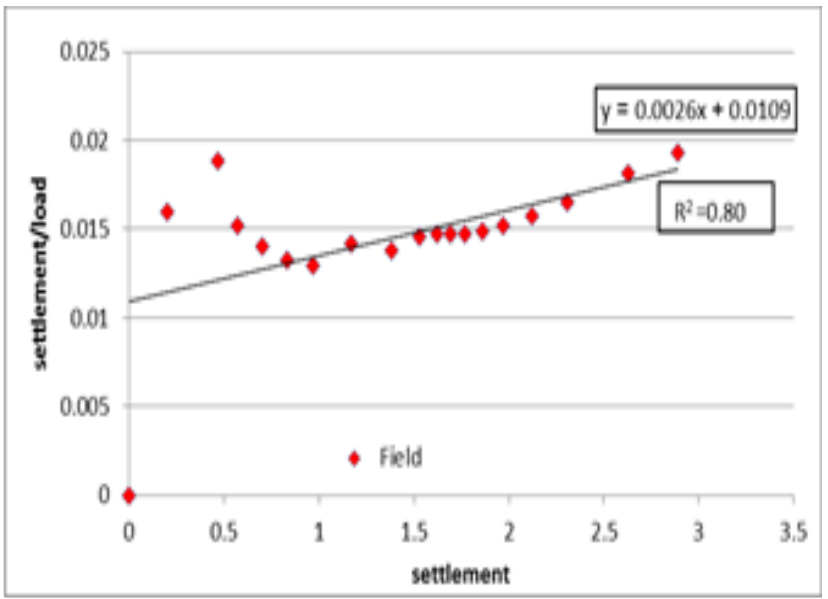

Fig.14. Relationship of Settlement/load Vs. Settlement for field test results

So, by applying the equation (2) at any settlement value, and the slope and interception of the straight line are known for each case, the pile capacity is easy to calculate. Thereafter, the ideal curves used to estimate the failure loads of bored piles can be generated.

The challenge of this step for the extrapolated results is to what level of settlement this technique is applicable and reliable. To afford an eligibility for this technique, the field extrapolated test results should be again validated with numerical results at predetermined level of settlement. Hence, the piles are loaded using the finite element analysis to the same pile displacement achieved in ChinKonder method. For all pile tests, the failure criterion adopted is a tangents method by which the failure load is defined as the load resulted from the intersection of two lines that are parallel to elastic and plastic parts in the load settlement curve. This method is almost applicable for all types of piles and gives rational results. The ideal loadsettlement curves generated for the both cases are illustrated in Figures 15 to 24.

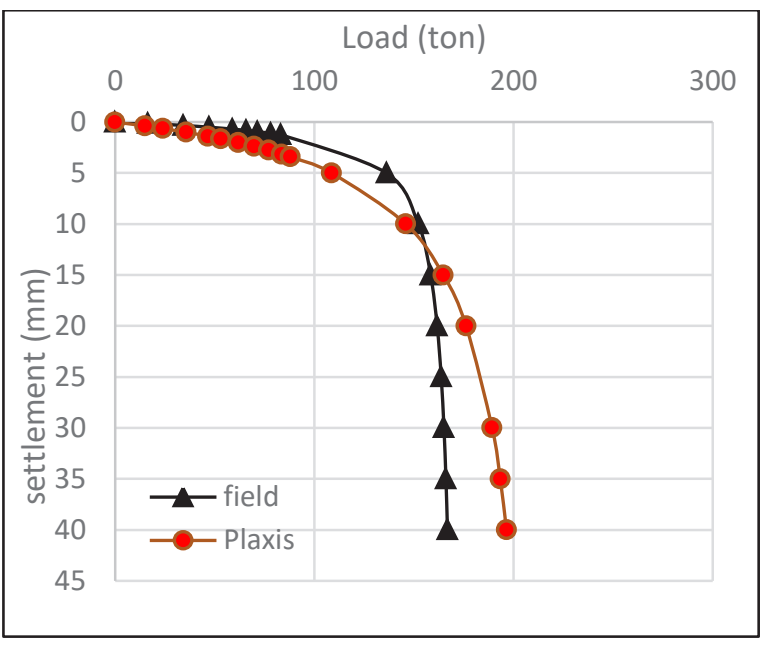

Fig. 15. Ideal load-settlement curve for bored pile under Clarifier Tank TP1

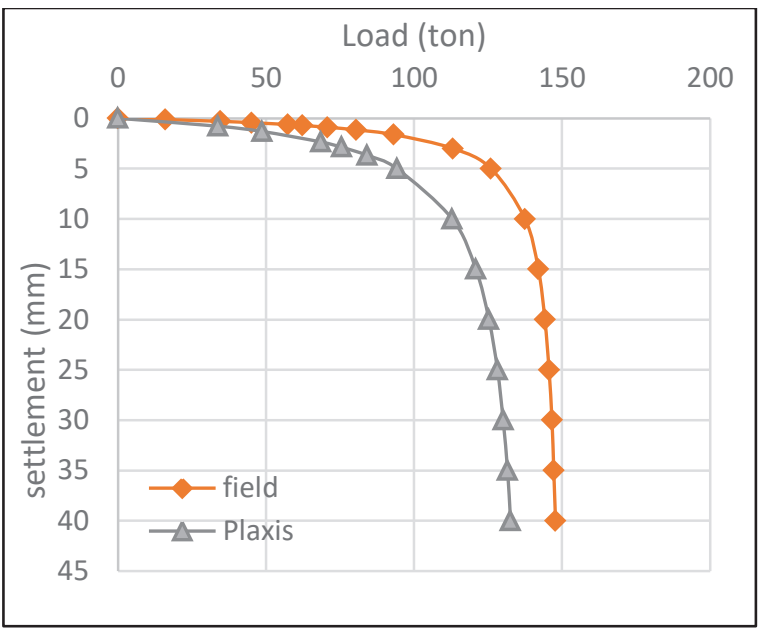

Fig. 16. Ideal load-settlement curve for bored pile under Clarifier Tank TP2

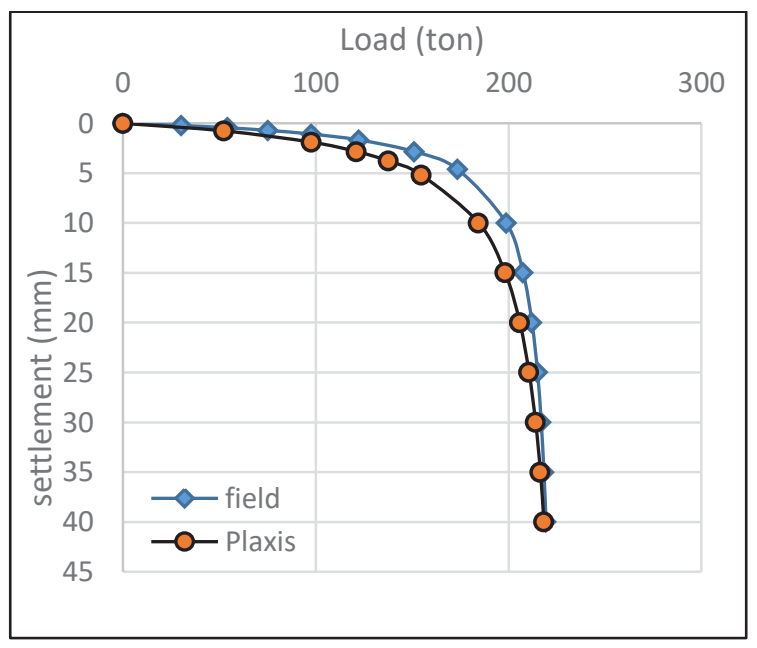

Fig. 17. Ideal load-settlement curve for bored pile under Aeration Tank 


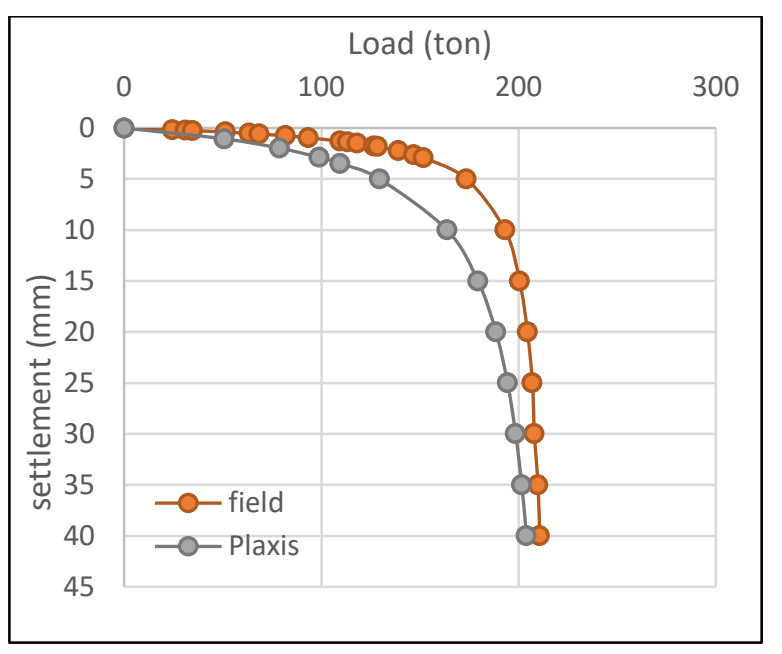

Fig. 18. Ideal load-settlement curve for bored pile under clarifier Tank TP3

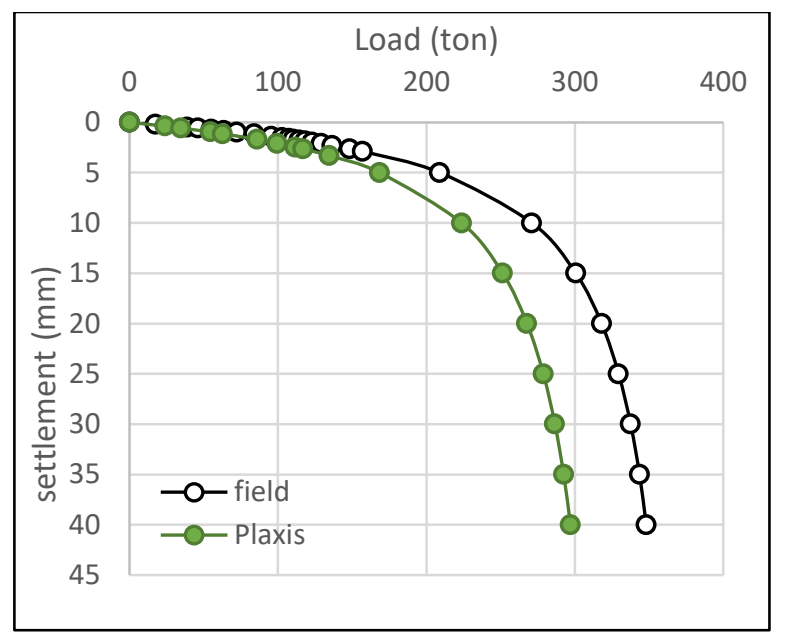

Fig. 19. Ideal load-settlement curve for bored pile under clarifier Tank TP4

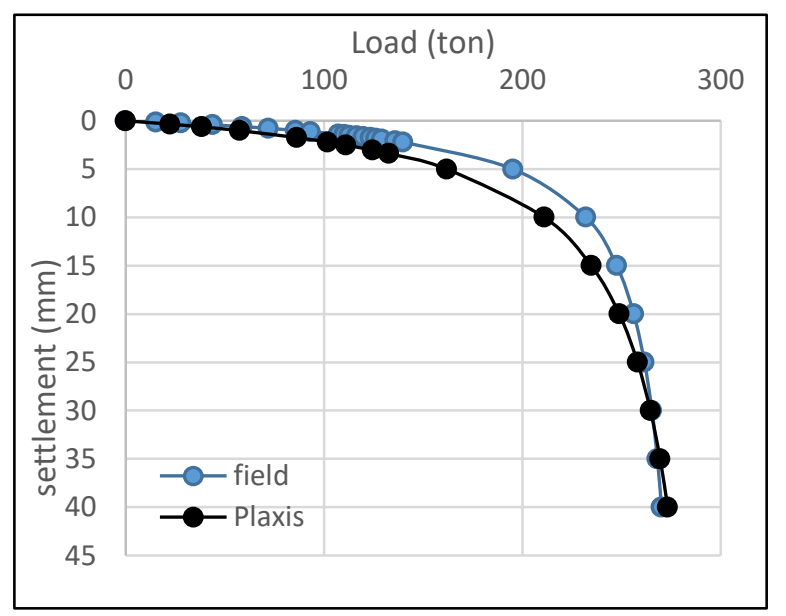

Fig. 20. Ideal load-settlement curve for bored pile under distribution chamber

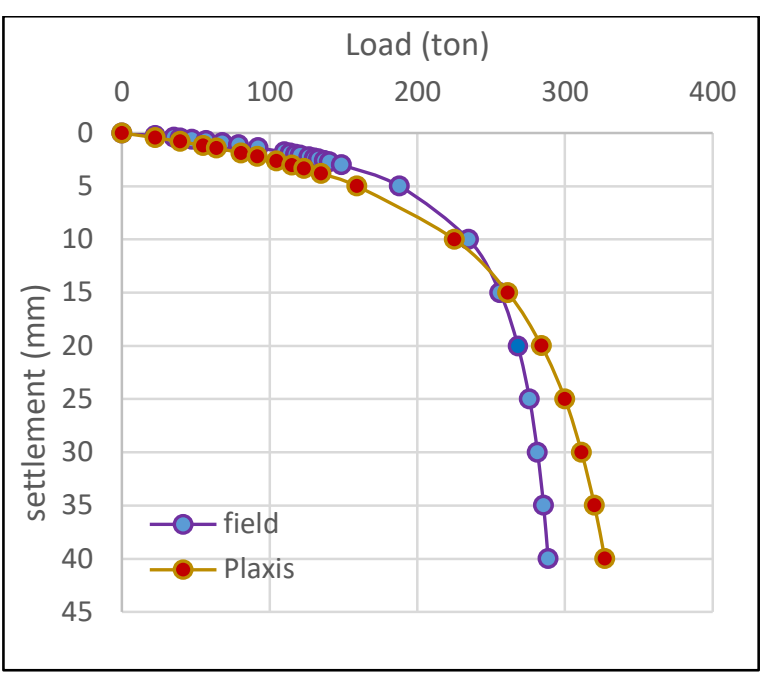

Fig. 21. Ideal load-settlement curve for bored pile under Effluent pumping station

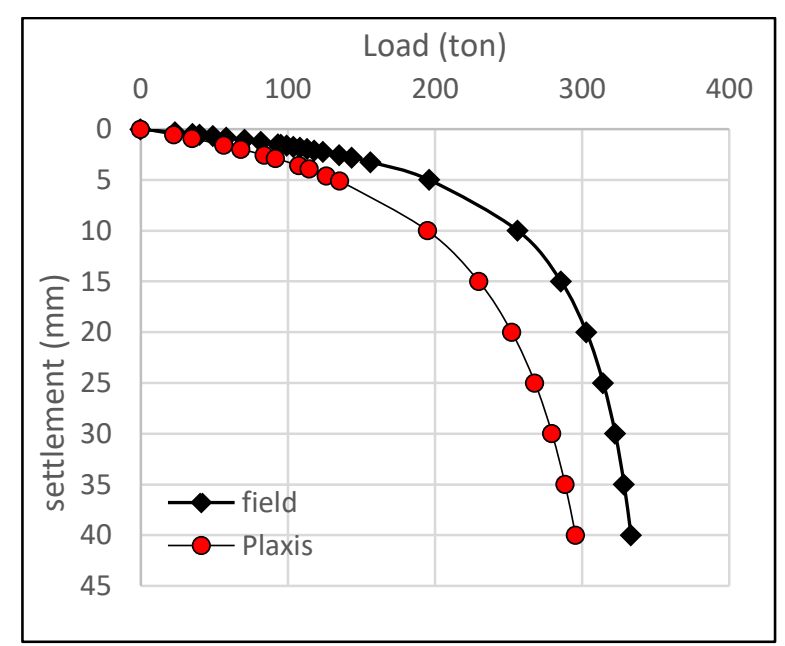

Fig. 22. Ideal load-settlement curve for bored pile under chlorination Tank

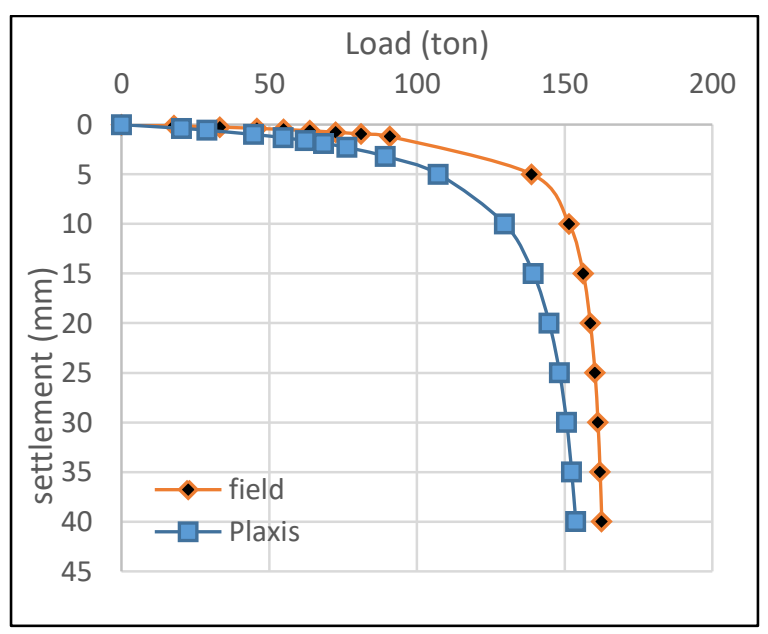

Fig. 23. Ideal load-settlement curve for bored pile under Portable water tank 1 


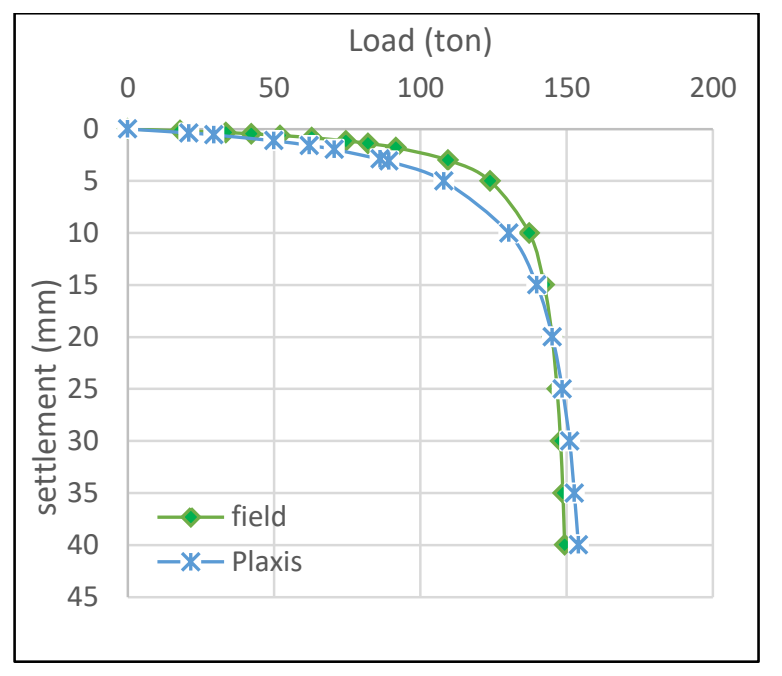

Fig. 24. Ideal load-settlement curve for bored pile under Portable water tank 2

It can be noted that, there is a good agreement between the numerical and field test results in term of pile capacity as they appear in Table 5. This absolutely indicates the reliability of the finite element analysis which may be accounted as an alternative approach in design of piles instead of traditional methods that are used in the analysis, in which it presents uneconomical option due to its underestimated response as compared with numerical analysis. The predicted ultimate capacities for all piles used in this study are listed in Table 5.

Table 5. Values of pile capacities obtained from the extrapolated field and numerical studies

\begin{tabular}{|c|c|c|c|c|}
\hline No. & $\begin{array}{l}\text { Type of } \\
\text { structure }\end{array}$ & $\begin{array}{c}\text { Testing } \\
\text { Load } \\
\text { (Ton) }\end{array}$ & $\begin{array}{c}\text { Pile } \\
\text { capacity } \\
\text { (Ton) } \\
\text { (Field) }\end{array}$ & $\begin{array}{c}\text { Pile } \\
\text { capacity } \\
\text { (Ton) } \\
\text { (Numerical) }\end{array}$ \\
\hline 1 & $\begin{array}{c}\text { Clarifier } \\
\text { Tank TP1 }\end{array}$ & 100 & 155 & 168 \\
\hline 2 & $\begin{array}{c}\text { Clarifier } \\
\text { Tank TP2 }\end{array}$ & 100 & 140 & 120 \\
\hline 3 & $\begin{array}{c}\text { Aeration } \\
\text { Tank }\end{array}$ & 180 & 210 & 195 \\
\hline 4 & $\begin{array}{c}\text { Clarifier } \\
\text { Tank TP3 }\end{array}$ & 150 & 200 & 180 \\
\hline 5 & $\begin{array}{c}\text { Clarifier } \\
\text { Tank TP4 }\end{array}$ & 150 & 305 & 255 \\
\hline 6 & $\begin{array}{c}\text { Distribution } \\
\text { chamber }\end{array}$ & 150 & 245 & 240 \\
\hline 7 & Effluent & 150 & 262 & 275 \\
\hline
\end{tabular}

\begin{tabular}{|c|c|c|c|c|}
\hline & $\begin{array}{l}\text { pumping } \\
\text { station }\end{array}$ & & & \\
\hline 8 & $\begin{array}{c}\text { Chlorination } \\
\text { Tank }\end{array}$ & 150 & 275 & 250 \\
\hline 9 & $\begin{array}{c}\text { Portable } \\
\text { water tank1 }\end{array}$ & 100 & 158 & 142 \\
\hline 10 & $\begin{array}{c}\text { Portable } \\
\text { water tank2 }\end{array}$ & 100 & 145 & 140 \\
\hline
\end{tabular}

Based on the results of pile capacity acquired through extrapolation process, the required new design load for each case can be obtained by dividing the failure load obtained from the ideal load -settlement curve of the field and numerical studies by a suitable factor of safety assumed before design, taking into the account the pile function (trial or working). The findings are outlined in Figure 25.

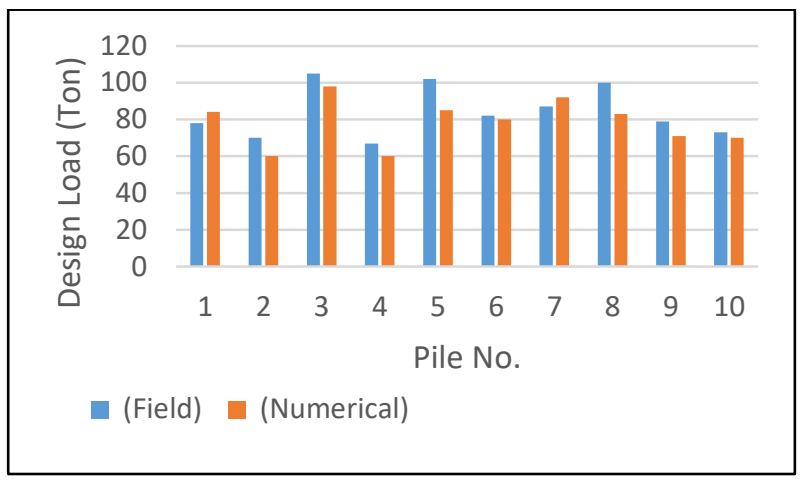

Fig. 25. Values of design loads induced from the extrapolated field and numerical results

Now, it is clear to say that; the feasible convergence between the numerical and field test results encourages the numerical methods to be drastically accounted in design instead or beside the conventional approaches especially for the cases when these ways are still incompetent to move on in solving these problems.

The average design load estimated was approximately 50 ton, and at this level of loading the failure mechanism have not plainly revealed. From the numerical analysis, the results exhibited an average design load about 76 ton at a set of ten piles. These new magnitudes of working loads can be utilized in design as a practical step by reducing the number of piles used under the structure, consequently minimizing the quantity of concrete required to execute the piles. Also, construction efforts will be decreased such as the transportation process in the site and time required to accomplish the pile installation also decrease.

Finally, the Plaxis program used in this analysis can be primly relied as a powerful tool in pile design, and by which the response of pile is moving close to the actual behavior of piles. 


\section{Conclusions}

Based on the finite element analysis performed using Plaxis 3D Foundation on full scale of bored piles during this study, the following major conclusions can be outlined as:

1. An excellent agreement was gained between the pile capacity obtained from the field and numerical test results. 2. The average design loads estimated from the extrapolated numerical analysis afford economical option, where the pile capacity obtained from this study is higher by about $51 \%$ than of that loads predicted using traditional methods.

3. The degree of convergence between pile capacities for both studies is about $90 \%$, this may give a suitable impression on the reliability of test results.

4. A Chin- Konder criterion has successfully proved its reliability in estimation of pile capacity at failure.

5. Finite element analysis using Plaxis program is considered as an effective alternative method in piles design.

\section{References}

1. ASTM D1143, Standard Test Method for Piles under Static Axial Compressive Load, New York, pp. 87-97, (1994).

2. ASTM D5434, Standard Guide for Field Logging of Subsurface Explorations of Soil and Rock1, New York, pp.1-3, (1997).

3. Das. B.M., Principles of foundation engineering”, 6th Edition, International Student Edition, United States, (2007).

4. Ehsan. M, M., H, N., G and R., N, Comparative Study on Prediction of Axial Bearing Capacity of Driven Piles in Granular Materials", Jr of Tek, (Sciences \& Engineering) 61, 15-20, (2013).

5. Hatanaka. M., and Uchida A., Empirical Correlation between Penetration Resistance and Internal Friction Angle of Sandy Soils, SAF, 36, 4, 1-10, (1996).

6. Michal. H., Jakub S., Comparison OF Numerical Analyses with a Static Load Test of a Continuous Flight Auger Pile", SJOCE, 22, 4, 1 - 10, (2014).

7. Naveen. B.P., T. G. sitharam, and S Vishruth, Numerical Simulation of Vertically Loaded Piles, Proceedings of Indian Geotechnical Conference, kochi, (2011).

8. Serhii. Lozovyi, Evhen Zahoruiko "Plaxis Simulation of Static Pile Tests and Determination of Reaction Piles Influence", USATJ, 2, 68-73, (2012).

9. Terzaghi, K., Peck R.B and Mesri, G., Soil Mechanics in Engineering Practice", Third edition, John Wiley and Sons Inc., New York, (1996).

10. Thounaojam, S., and ParbinSultana, Prediction of Bearing Capacity of Bored Cast- in Situ Pile, JOMACE, 16, (2015). 